\title{
Characterization of salt-affected soils of Faizabad district
}

MANEESH KUMAR, NEERAJ KUMAR, VED PRAKASH, S. K. YADAV, ADESH KUMAR AND RAM BHAROSE

MEMBERS OF RESEARCH FORUM:

Corresponding author : MANEESH KUMAR, Department of Soil Science and Agricultural Chemistry, College of Agriculture, Narendra Deva University of Agriculture and Technology, Kumarganj, FAIZABAD (U.P.) INDIA Email: maneeshkumar02@gmail.com

Co-authors : NEERAJ KUMAR, VED PRAKASH, S. K. YADAV, ADESH KUMAR AND RAM BHAROSE, Department of Soil Science and Agricultural Chemistry, College of Agriculture, Narendra Deva University of Agriculture and Technology, Kumarganj, FAIZABAD (U.P.) INDIA

Email: skyadav42@rediffmail.com

Received : 25.01.2016; Revised : 30.03.2016; Accepted : 26.04 .2016

\section{Summary}

A study was undertaken to characterize the soils of Faizabad district, Uttar Pradesh in order to assess their land capability. The soils were described in the morphology, characteristics. Themorphological properties of soils were studied and later on analyzed in laboratory for their physical and chemical properties. Thickness of Ap horizon was less in pedon number $1(20 \mathrm{~cm})$, pedon number 2 and $3(22 \mathrm{~cm})$ and pedon number 4 and $5(25 \mathrm{~cm})$. The solum depth of all the profiles ranged from 85 to $100 \mathrm{~cm}$. The colour of surface soil of pedons 1, 2, 3, 4 and 5 were light gray (10 YR 7/1 and 10YR 7/2) when dry and light yellowish brown (10 YR 6/4) when moist. The soil colour of sub-surface horizons was strong brown (7.5YR 5/6). Surface soil structure of the pedon was fine prismatic while it was fine sub-angular blocky of other pedons. The consistency of surface and sub-surface soils varied from slightly hard to very hard, friable to extremely firm.It was non-sticky, non-plastic to sticky, plastic in dry, moist and wet conditions, respectively in all the pedons.

Key words : Pedon, Horizon, Structure

How to cite this article : Kumar, Maneesh, Kumar, Neeraj, Prakash, Ved, Yadav, S.K., Kumar, Adesh and Bharose, Ram (2016). Characterization of salt-affected soils of Faizabad district. Asian J. Soil Sci., 11 (1) : 98-102 : DOI : 10.15740/HAS/AJSS/11.1/98-102. 